\title{
AMAZON LANDFORMS AND SOILS IN RELATION TO BIOLOGICAL DIVERSITY ${ }^{1}$
}

\author{
Wim Sombroek ${ }^{2}$
}

\begin{abstract}
Thirteen main landform units are distinguished for the whole of the forested Amazon region, each with its specific soil pattern and vegetation structure. These landform-soil-vegetation units are delineated on a small-scale map and illustrated by a schematic cross-section. Floristic diversity of the gamma type is to be highest on the steepland-and-valley complexes of the Andean fringe, on the crystalline shield uplands, on the inselberg complexes, and on the eutric variant of the western sedimentary plains. Endemism is expected to be highest on the sandy plains, and parts of the table lands and inselberg complexes. Speciation, linked to the concept of forest refuge areas, is likely to be highest on the sandstone table lands, on the stretches of Amazon planalto, and in the areas of relict valleys, in view of the prolonged geomorphological stability of these units.
\end{abstract}

Key-words: Amazon, major landforms, tropical soils, floristic biodiversity.

\section{Paisagens Maiores da Amazônia e seus Solos em Relação com a Biodiversidade}

RESUMO - Foram distinguidas treze unidades de paisagens maiores, em toda região Amazônica florestada, cada unidade com padrão de solos e estrutura de cobertura vegetal específica. Estas unidades de paisagem-solos-vegetação foram delineadas num mapa geral da região e ilustradas por um corte transversal esquemático. A diversidade florística, do tipo gamma, deve ser a mais alta no complexo paisagistico da Selva Alta, bordeando a Cordilheira Andina; nas terras firmes colinosas dos escudos cristalinos; no complexo de inselbergs, e no variante eutrico das terras firmes sedimentárias ocidentais. Estima-se que o endemismo seja mais alto nas planícies arenosas, e em partes dos complexos de chapadões e de inselbergs. Especiação, ligada com o conceito de refúgios florestais, é provavelmente mais alta nos chapadões de areniscos antigos, nas extensões do planalto Amazônico, e nas áreas de vales relictos, considerando a estabilidade geomorfológica prolongada destas unidades.

Palavras-chave: Amazônia, unidades de paisagem; solos tropicais; biodiversidade florística

\section{INTRODUCTION}

Two international workshops to define priority areas for conservation in Amazonia, on the basis of biogeographic maps of the region, were held in Manaus, Brazil, January 1990, and Macapa, Brazil, September 1999 respectively. They recognised the need to augment the aggregated information on flora and fauna with geographically-oriented studies on the Amazon climates, geomorphology/landforms, soils, hydrology/limnology, and human population patterns. The reasons are threefold:

-The characteristics and history of the physical and human resources may explain some of the observed spatial differences in the various aspects of floral and faunal species diversity;

\footnotetext{
'A preliminar version of this text appeared in ISRIC Annual Report over 1990, Wageningen, the Netherlands. Updating and digitizing of the coloured map took place in 1998. The digital version can be obtained separately from the author in Holland or from GTZ/PPG7/IPAAM, Manaus.

${ }^{2}$ Consultant GTZ/PPG7/IPAAM; Manaus, Am. Brazil; e-mail: gtz@ipaam.br

Permanent adress: ISRIC, P.O.Box 353, 6700 AJ Wageningen, Holland. Fax: + 31317471700 ; e-mail: sombroek@isric.nl
} 
-The geography of these resources may help in establishing boundaries of biogeographic units in areas where the number of observations on flora and fauna is scarce or skewed;

-The ecological fragility of the physical resources themselves may constitute a reason on its own to include certain areas in the map on priority areas for conservation.

The present text deals with the aspects of landforms and soils. It is accompanied by a coloured sketch map on landforms (Fig. 1), a schematic cross section of the region showing the relationships between landforms, vegetation and soils (Fig. $2 \mathrm{a}$ ), as well as a drawing of the main soil profiles involved (Fig. $2 b$ ).

Knowledge on landforms, soil conditions and their biota of the Amazon region has long remained rudimentary (Sombroek, 1966; Ab'Saber, 1967) because of difficult access of this largest area of tropical forest in the world. In recent years, however, this has changed considerably. This not only because of the construction of a network of roads, but especially through the availability of airborne radar images as produced by government entities of Brazil, Venezuela, Colombia, and Peru. For instance, the results of multidisciplinary surveys on the basis of radar photography are contained in a series of volumes, with $1: 1.000 .000$ scale maps, of Radambrasil (1972-1981) and for Colombia on 1:500.000 scale maps by Proradam (1979).

On the basis of such new infor- mation, a schematic synthesis of the landforms is presented, with postulations on their origin and degree of stability during the Cenozoic era. It draws, in part, on the comprehensive study on the land systems of the central lowlands of tropical South America by Cochrane et al. (1985; with map at 1:5M). It should be mentioned that for the Brazilian part a geomorphologic map at scale $1: 2.500 .000$ has been published recently by SAI/IBGE (1998), presenting a more detailed scheme (43 tipos de modelados fisiográficos)

With each main landform a nontechnical description of the predominant soils is given. Only the FAO/ Unesco terminology for soil classification (FAO, 1974; 1988) is used. For the naming in other systems such as the US "Soil Taxonomy" and the Brazilian scheme, see the review of Sombroek (1984). The latter text gives also more details on the physicochemical characteristics and properties of the soils, with an assessment of their agricultural potential and references to the pertinent soil literature.

The landform and soil descriptions are accompanied by an indication of the structure of the present-day vegetative cover. For soil-vegetation relationships see also Brown (1987) for the Brazilian part, and Huber (1982) for the Venezuelan part of the region.

Floristic species occurrence in relation to soil and landform conditions is discussed in the second part of the paper. 


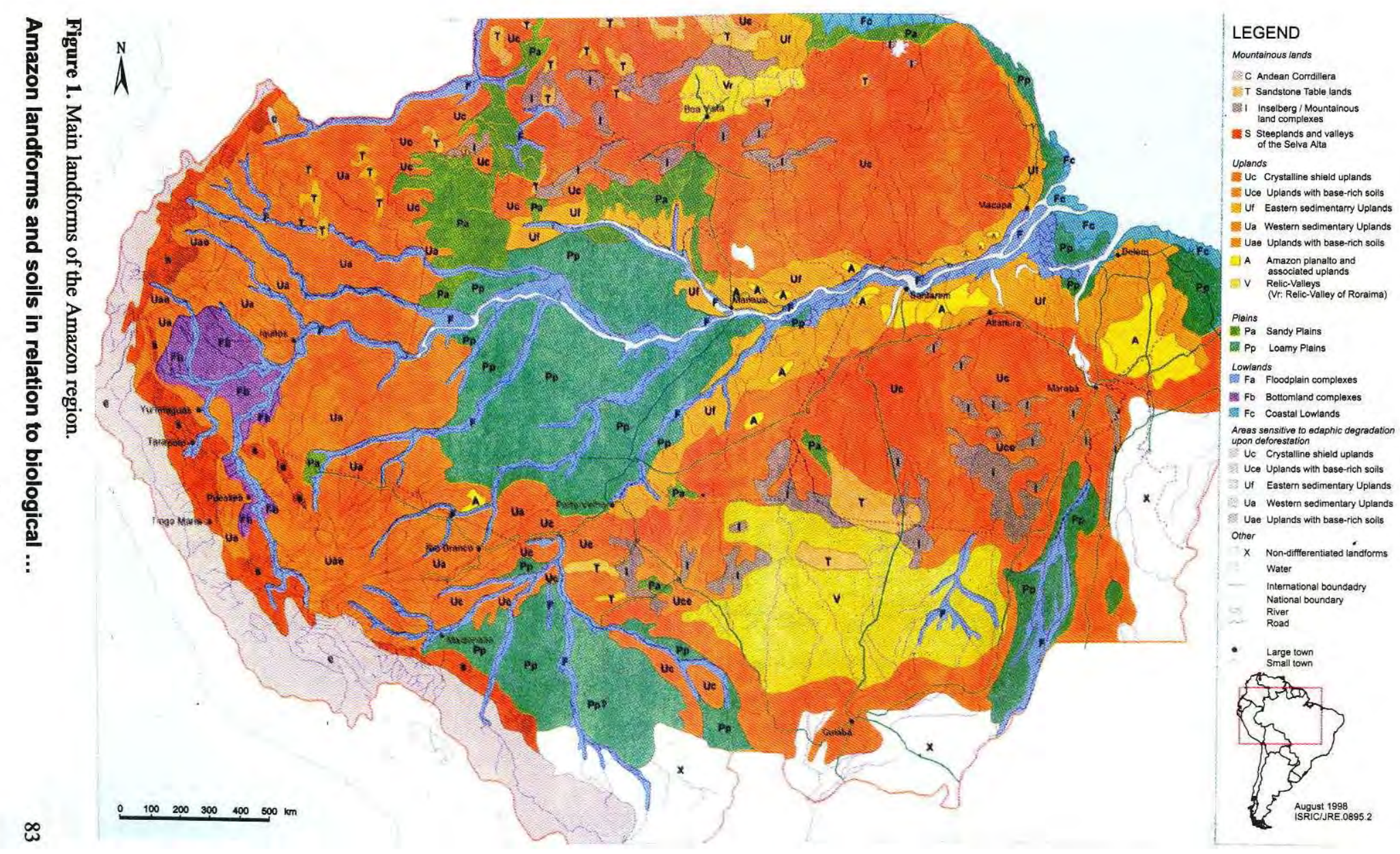




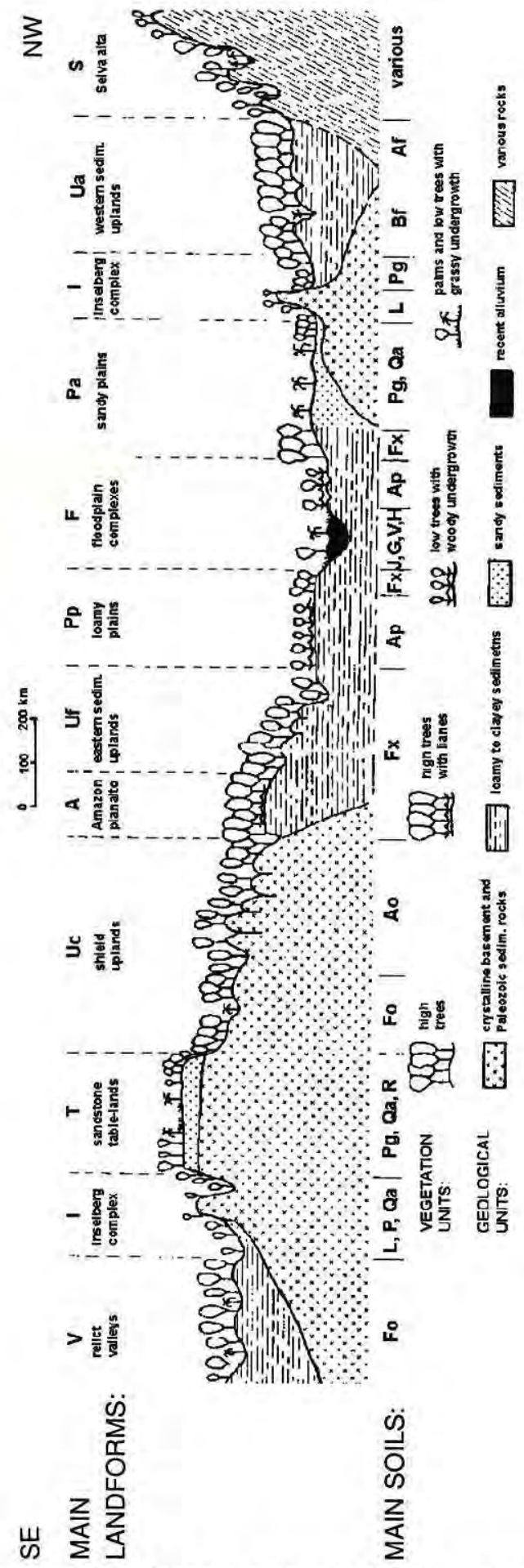

Figure 2a. Schematic cross section of the region showing the relationships between landforms, vegetation and soils 

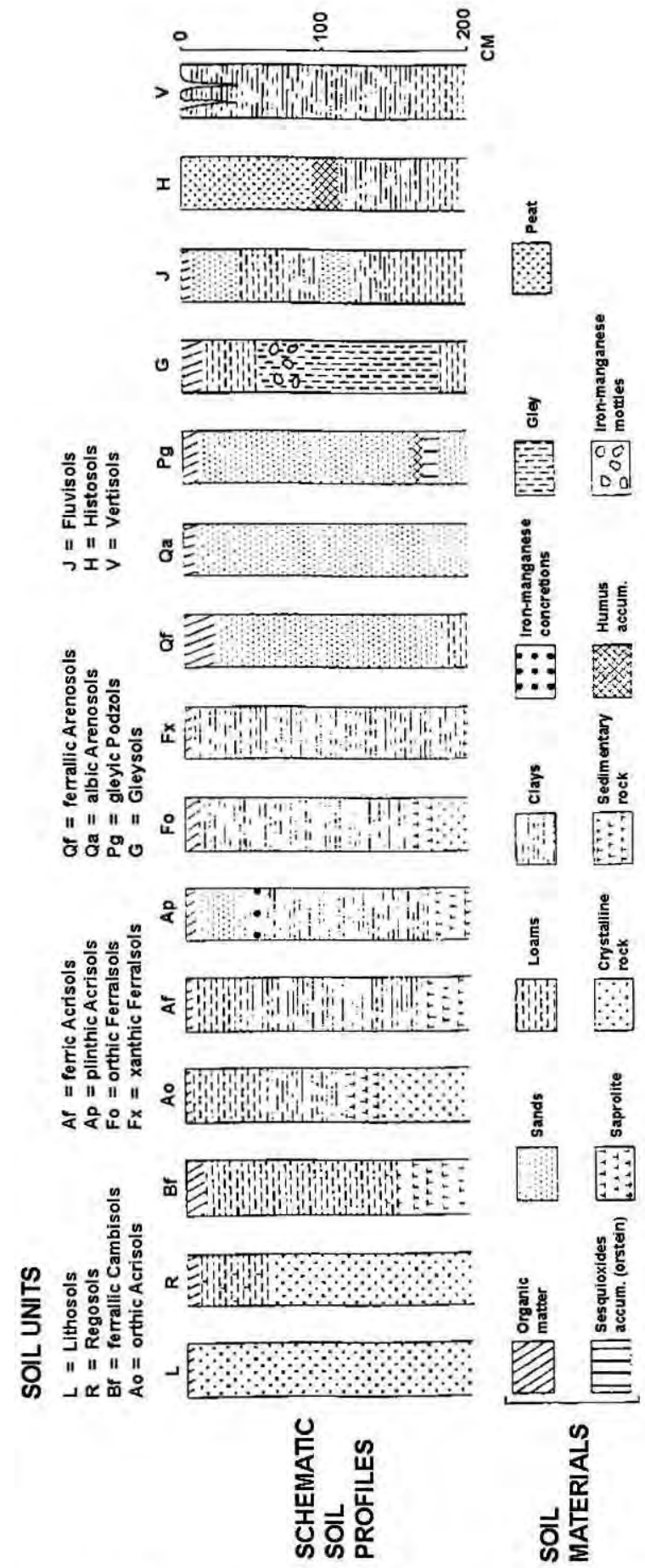

Figure $2 \mathrm{~b}$. Schematic profiles of the main soils of the cross section of figure $2 \mathrm{a}$ 


\section{LANDFORMS, SOILS AND VEGETATIVE COVER}

\subsection{Mountainous Lands}

2.1.1. Flat to gently undulating high-level (> $500 \mathrm{~m}$ alt.) table lands, mainly formed by weathering-resistant arkosic sandstones (Proterozoic Roraima formation and others), are concentrated in the water divide regions of the main tributaries of the Amazon. Examples of these SANDSTONE TABLE LANDS (symbol T of the maplet) are the "tepuis" of Venezuela, the "chapadões" of Brazil and the "mesas" of the Colombian part. It is assumed that these table lands are geomorphologically stable since Cretaceous times, if not earlier, although the process of upheaval may have lasted until the Pleistocene (Kubitzki, 1989).

The soils of these sandstone table lands are predominantly shallow, sandy and podzolised (albic Arenosols; Podzols; Lithosols). They support at present a savanna or low-forest vegetation ("campina rupestre"). The scarps have often stony soils, with more vegetative cover than the flat tops.

2.1.2. Steeplands occur on weathering-resistant parts of the crystalline shields. These are the INSELBERG COMPLEXES (I) of the frontier zone Guyana-Brazil-Venezuela-Colombia, the mountainous lands of the Brazilian shield, and associated colluvia and alluvia. Reshaping of the land has likely taken place all through the Pleistocene.
The inselberg complexes have a catenary sequence in soil conditions. Bare rock outcrops and very shallow soils (Lithosols) of the inselbergs themselves and other mountainous parts alternate with deep, often sandy soils (albic and ferralic Arenosols) on the colluvia at the feet of the inselbergs, and yellowish to reddish loamy soils on the bands of welldrained uplands and alluvia in-between (xanthic Ferralsols and Acrisols). The inselbergs have a shrubby vegetation, the footslopes a mosaic of forest and savannah, while the uplands and alluvia support high forest.

2.1.3. Steeplands, interhill valleys and colluvial fans are found in the Andean fringe, on a variety of geologic materials: the SELVA ALTA (S) areas of Colombia, Ecuador, Peru and Bolivia, with geomorphologic dissection still active.

These steepland-and-valley complexes have an extremely strong variation in soil conditions, as a consequence of the prevalent short-distance variation in lithology, slope position and meso-climatic conditions (the area around Tarapoto in Peru has even a subhumid climate, with a long dry season). A schematic subdivision is as follows: Rock outcrops or shallow and stony soils (Lithosols; shallow phases of Cambisols) are found on steep upper slopes; they often carry low forest only. Well-drained, deep, reddish, loamy to clayey and in part stony soils with variable ion exchange capacity, base saturation, and mineral reserve 
(Ferralsols, Acrisols, Luvisols, Nitisols) are found on the middle slopes, and they support high forest. Bands of Pleistocene terrace lands may have a strong internal differentiation in texture and acidity ("duplex" or claypan soils: Planosols), on which a shrubby vegetation prevails. Low upland and bottomland parts can have base-rich cracking clay soils (Vertisols) with a scrub vegetation, while floodplain stretches have base-rich silty soils (Fluvisols) with high forest.

\subsection{Uplands}

2.2.1. Rolling to hilly dissected lands and rounded hills with convex slopes are found on the crystalline basement rocks where weathering resistance is smaller than in the inselberg areas, as well as on adjacent outcropping Paleozoic-Mesozoic sedimentary rocks. They occupy the main part of the Guyana and Brazilian shield areas and can be denominated as CRYSTALLINE SHIELD UPLANDS (Uc). Dissection has presumably been active as recent as in the Late Pleistocene. In places the terrain may be only gently undulating, constituting remnants of early planation surfaces ("Sul-americana" and "Velhas" levels of King, 1957).

The shield uplands have often a short-distance variation in soil conditions. Areas with steep slopes or resistant rocks have rather shallow soils, with a substantial content of weatherable minerals (Cambisols). Most of the soils are deep to rather deep, well-drained, reddish, loamy to clayey and acid. Part of them have a textural differentiation with relatively compact subsoils, a reserve of weatherable minerals and varying clay-mineral activity (ferric or orthic Acrisols); these soils often sustain an open-canopy forest with a dense undergrowth. Other soils are more homogeneous in their vertical build-up, with little or no weatherable mineral reserve and an inactive clay mineralogy (orthic and rhodic Ferralsols); these carry predominantly closed-canopy high forest.

Areas with a substratum of dioritic crystalline rocks, basalts, or ferromagnesian rich Paleozoic-Mesozoic sedimentary rocks have dusky red, deep and clayey soils of good structure, with a high percentage of active clay-sized iron oxides (Nitisols). These so-called "Terra Roxa Estruturada" soils of the Brazilian soil classification system occur along parts of the Transamazon highway; in the middle Xingu area, and in Rondonia (unit Uce of figure 1; Camargo, 1981). They support a luxuriant forest cover, but are also much sought after for permanent settlement (cocoa growing!) because of their favourable physical and chemical properties.

2.2.2. Flat, intermediate-level plateaux (100-300 $\mathrm{m}$ alt.) occur in the eastern part of the sedimentary basin, with a cover of kaolinitic sedimentary clay. This is the AMAZON PLANALTO (A) with the so-called Belterra clay, probably of lacustrine or inland-sea origin. These plateau lands, often with steep scarps, prevail between the lower reaches of the Tapajós 
and Xingu rivers (see maplet in Klammer, 1984), as well as in the upper reaches of the Gurupi catchment (Sombroek, 1966, p. 18-26 and appendices 1, 4 and 5). The plateau remnants have not been dissected in the Pleistocene epoch.

The Amazon planalto has a monotonous cover of very deep, very clayey, acid, yellowish soils of very low physico-chemical activity and no mineral reserve (xanthic to geric Ferralsols). Most of them are porous and friable to great depth and then support high, closed-canopy forest. Central parts of planalto stretches, far away from the scarps, can have compact subsoils; in these cases the vegetative cover is a liana-rich open-canopy forest, or even pure liana forest or "cipoal" (Sombroek, 1966, p. 194-196). The latter vegetation type predominates on the left bank of the lower Xingu and may be the enduring result of past Amer-indian occupation (Balée \& Campbell, 1989).

Contrary to early suppositions (Sombroek, 1966), the Amazon planalto stretches with Belterra clay cover turn out to be of very limited occurrence in western Amazonia. Only isolated patches have been identified, for instance along the road from Rio Branco to Sena Madureira (Acre, Brazil) and north-west of Boca do Acre in Amazonas state (map unit LVd4 of Radambrasil, Volume 12). In the Colombian part some Amazon planaltolike plateau rests were recently mapped for the middle Caquetá area (map units Sp1/Sp2 of Duivenvoorden and Lips, 1995), while for the Peruvian part of the sedimentary basin the "restos pequeños de acumulación planos" on resistant layers of Tertiary deposits, as mentioned by Khobsi et al. (1980), would be concerned. The soils of these western Amazon Belterra clay plateau-rests are less heavy in texture $(50 \%$ clay size particles instead of the $80-95 \%$ of eastern Amazonia) while their subsoil compactness may have induced the formation of claypan soils (dystric Planosol of unit Sp2 of Duivenvoorden \& Lips, 1995).

2.2.3. Gently undulating, relatively high lying land with concave slopes can be found on either crystalline basement or Cretaceous-Tertiary deposits. These can be denominated RELICT VALLEYS (V) and prevail in the southern fringe of the region (headwaters of the Xingu and the Tapajós rivers in northern Mato Grosso, 400-500 m. alt.). They can also be observed locally in the central basin, for instance in the upper reaches of the Curua-una river southeast of Santarém (Klammer, 1984, p. 64-65), the upper reaches of the Capim river south of Belém, and in some sections of the sedimentary area between Manaus and Itacoatiara. In the latter cases it apparently often concerns an Early Pleistocene remodelling of Belterra clay by erosion and short-distance re-deposition, without any dissection in later parts of the Pleistocene.

The areas of the relict valleys with their gentle concave slopes have 
predominantly very deep, sandy loam to clayey and sometimes concretionary, acid, yellowish to reddish soils of low to very low physico-chemical activity (xanthic or orthic Ferralsols and ferralic Arenosols). They support high forest of large timber volume unless climatic conditions are marginal, such as in the uppermost reaches of the Xingu and Tapajós catchments.

The savannah areas around Boa Vista (Roraima State of Brazil) may constitute a variant $(\mathrm{Vr})$ of these relict valleys. In the past the area was apparently in direct hydrographic contact with the Atlantic Ocean through the present-day Essequibo river valley of Guyana, which forms part of the Takutu basin, an intra-continental NESW running rift valley structure dating from the Jurassic (McConnell et al., 1969). During the Sicilian or Milazzian glacio-eustatic high sea level of the Early Pleistocene (Zeuner, 1959) the Boa Vista area may have been a small inland sea or bay of this rift valley, during which time the sediments of the Boa Vista Formation were deposited.

The Boa Vista relict valleys have predominantly a savannah cover because the soils have a strong textural differentiation (sandy topsoils over compact, clayey subsoils) and/or occurrence of massive ironstone layers (Arenosols, Planosols, Plinthosols, ironstone Lithosols). Also because of locally high $\mathrm{Mg} / \mathrm{Ca}$ ratios in the deeper subsoil and the presence of "whale-wallow" or "olho-de-água" type of terrain depressions (cf.
Carneiro Filho, 1991), it is believed that this divergent soil development is due to a brackish-water lagoonal depositional character of the parent materials (cf. Sombroek et al., 1970, for similar features in the Lagoa Merim area of southern Brazil). Dry climatic conditions during parts of the Pleistocene, as evidenced by the occurrence of fossil sand dunes (Carneiro Filho \& Zinck, 1994), may have contributed further to strong textural differentiation of most soils.

2.2.4. An alternation of flat and undulating land, the latter often with convex slopes, is found in the Pleistocene glacio-eustatic terrace levels in the eastern part of the Amazon basin. These stepped depositional plains, or EASTERN SEDIMENTARY UPLANDS (Uf), occur on fluviatile sediments derived from crystalline shield material that was pre-weathered during the Cretaceous and Tertiary. Dissection has taken place throughout the Pleistocene due to pluvial-interpluvial climatic alternations and base-level oscillations, as demonstrated by Klammer (1984).

The eastern sedimentary uplands have well-drained, very deep, acid, yellowish soils with textures that vary laterally from loamy sand to light clay with low percentages of silt, but that are vertically homogeneous. The soils have no weatherable mineral reserve and are physico-chemically very inactive, especially on the flat parts of the upper terraces (Sombroek, 1966, p. 167-171); but they are porous and friable throughout (xanthic or geric 
Ferralsols; some ferralic Arenosols). They support a closed-canopy high forest of large to fair timber volume. In part, the soils contain ironstone concretionary layers, but this has normally no detrimental effect on the forest structure. Very sandy patches on the higher uplands may have a white-sand soil profile, but then without any water-stagnating subsoil layer. Such patches of albic Arenosols or "Giant Podzols" also support closed-canopy forest, be it of low timber volume; at disturbance by present or past occupation there is, however, no forest regrowth.

2.2.5. Undulating to rolling land, often with convex slopes occupies the western part of the basin, on sediments derived from the Andean Cordillera by fluviatile and sometimes volcano-eolian deposition. Also these WESTERN SEDIMENTARY UPLANDS (Ua) have undergone dissection throughout the Pleistocene.

The soil conditions contrast distinctly with those of the eastern sedimentary uplands described above, because most sediments were less preweathered at the time of their deposition. The soils are also predominantly deep, well drained, yellowish red and acid, but they have a different clay mineral assemblage that results in higher ion-exchange capacities. The over-all textures vary, but the silt content is relatively high, and there is some reserve of weatherable minerals. Many of these soils show a substantial textural differentiation and the deeper subsoils may show reddish mottling (pseudo-plinthite, i.e. not hardening upon exposure). These ferric or haplic Acrisols and Alisols (FAO, 1988) have a forest cover of predominantly rather open canopy structure.

A recent multi-disciplinary survey of the Peruvian Amazon Region near Iquitos has shown that the soils of the Tierra Firme area are dominantly strongly leached and very acid, hence poor in plant nutrients (Ferralsols, Acrisols, ferralic Cambisols, some Podzols and Arenosols). A minor part of the Tierra Firme soils has a substantial reserve of plant nutrients, based on the presence of non-weathered Tertiary clay deposits of the Pebas formation in the shallow subsoil. This situation seems to be restricted to the denudated land along incising rivers, valleys and depressions (Kauffman et al., 1998). Floristic observations show correlations with these soil groups, especially with their texture and the content of exchangeable bases (Ruokolainen \& Tuomista, 1998).

Soil mapping in the Colombian part (Duivenvoorden \& Lips, 1995) has revealed that two mega-level soil associations are concerned: (i) the higher-activity Ali-Acrisol association being physiographically linked to the lower terraces and the Pebas clays of brackish-water depositional nature, and (ii) the low-activity Acri-Ferralsol association, linked to the higher terraces of pre-weathered fluviatile sandy to clayey sediments derived from the Guyana shield and the Proterozoic 
arkosic sandstone formation.

In the south-western part, viz. Acre state of Brazil and the adjoining part of Peru (tentative unit Uae on the map), soils with high base status occur, due to the presence of richer sedimentary deposits and in places also volcanic ash admixtures (Möller \& Kitagawa, 1982). The soils are either deep (ferric Lixisols) or shallow (eutric Cambisols). The forest structure is determined by the occurrence of bamboo (Guadua superba), either scattered or in dense stands (Cardoso da Silva et al., 1990); the dense stands may be the result of erstwhile Amerindian burning practises.

Some of the soils of the northwestern sedimentary uplands, notably in the Ecuadorian part (also unit Uae), show little or no textural differentiation. They have either a high base saturation (eutric Cambisols, eutric Nitisols) or are acid (ferralic Cambisols); in both cases high and closed-canopy forest prevails.

\subsection{Plains}

2.3.1. Flat to gently undulating, relatively low-lying lands with a sandy surface over basement rocks are prevalent in the Rio Negro and middle Rio Branco areas. It is speculated that these denudational SANDY PLAINS $(\mathrm{Pa})$ were formed in the Late Pleistocene, after capture of some of the former tributaries of the Orinoco and Essequibo rivers by the Amazon river system. This capture would have resulted in a sudden huge increase in river discharge of the Amazon tributar- ies, causing a selective removal of the clayey components of Early Pleistocene or Tertiary-Cretaceous sediments that may have covered the areas originally. Sandy plains also occur in a band between the crystalline uplands and the coastal floodplains of the Guyanas, notably near the mouth of the Essequibo river.

The sandy plains of the Rio Negro and middle Rio Branco areas and of the Guyanas have year-round imperfectly drained soils. They are characterized by a subsurface horizon that consists of light grey to white sand or loamy sand of single-grain structure. This is underlain by a subsoil, at strongly varying depth, that is homogeneously or banded dark brown to black, with a texture that is only little heavier than the overlying layer but with a firm consistence or even cementation, causing low water permeability and poor root penetrability. This hardpan, or "Ortstein", may be continuous or show a very irregular lateral pattern to the extent that in places it may be completely absent. The soil is very acid throughout and has no reserve of weatherable minerals at all (gleyic Podzols, or albic Arenosols if the white layer is thicker than $200 \mathrm{~cm}$ ). The natural vegetation on such soils is either a savannah with common bare sand patches ("campina" or "bana") or a closedcanopy low forest often with a scleromorphic physiognomy ("caatinga amazonica"). Clearing of this vegetation would result in permanent exposure of the white sandy soil. The sandy plains 
of the middle Rio Branco have traces of past eolian deformation, visible on Landsat TM images of the area.

2.3.2. Flat to gently undulating, relatively low-lying lands with fine sandy to silty sediments are prevalent in the lower Juruá-Purus-Madeira river areas south-west of Manaus. These are apparently plains with Late Pleistocene unstable sediments, recently denominated "Içá" formation by the Brazilian Geologic Service (CPRM, 1998). Their unstable character has resulted in exceptionally wide bands (often $50 \mathrm{~km}$ ) of low terrace land and floodplains along the rivers crossing the area. The surfaces of these LOAMY PLAINS (Pp) still show relict features of meandering rivers, as demonstrated by Klammer (1984) and Irion (1976 et seq.) The deposits may have originated from the postulated Late Pleistocene or Early Holocene disengorgement of an antecedent of Lake Titicaca in the Altiplano area of Bolivia and Peru, which would have resulted in a huge temporary interior lake (Campbell et al., 1985; Frailey et al., 1988).

The loamy plains have seasonally imperfectly drained soils of low structural stability. A silty-loam topsoil overlies a silty-clay subsoil that has a compact consistence with prominent, coarse and abundant red mottles in a light grey matrix. The centres of these mottles are usually hardened, and at the transition zone between topsoil and subsoil a thin layer of discrete iron-manganese concretions may occur. The mottles, called "plinthite" in modern soil science, become irreversibly hardened to slag-like material upon exposure to the open air for several seasons and are then known as petroplinthite, laterite concretions, or "ironstone". The base saturation in the soil is low throughout, and the physico-chemical activity of the clay minerals is low to very low. These soils are comparable with the "groundwater laterites" of early pedological literature (Marbut, 1932), but nowadays denominated Plinthosols when the plinthite is shallow and strongly developed, or plinthic Acrisols when the plinthic material is deeper or weaker. Their vegetation consists of forest of relatively low biomass (timber volume of $100-150 \mathrm{~m}^{3}$ per ha), often with a predominance of palms on the gently sloping parts, and of a shrubby or open grass savannah ("campo") on the flat interfluves. Clearing of the latter vegetation would result in irreversible hardening of some of the plinthitic subsoil, which may be aggravated upon erosion of the unstable topsoil.

Late Pleistocene plinthitic plains are also found in the Beni area of northeastern Bolivia, in the lower GurupiMaracassumé area of northern Maranhão, on the west bank of the lower Tocantins river and the erstwhile continuation there-of on the south-eastern fringe of Marajó island (Camargo, 1981). Most of them are less silty than those of the Içá sediments.

\subsection{Lowlands}

2.4.1. Flat lands and inland wa- 
ters alongside the major rivers constitute Holocene floodplain generations. Details of these FLOODPLAIN COMPLEXES $(\mathrm{Fa})$ are given by Sutmöller et al. (1966) and Klammer (1984, p. 68).

The floodplains along the major rivers have a strong short-distance variation in soil conditions. A broad grouping as "alluvial soils" can be made because the sedimentary stratification still overrides any pedogenetic profile development. However, the soils vary much in texture, internal drainage conditions, organic matter content, acidity, and clay mineralogy - depending on the local flooding conditions, the source of the sediments and the time elapsed since their deposition or re-deposition (Fluvisols, Gleysols, gleyic Acrisols, Vertisols, Histosols).

In general, the floodplains with sediments from the Andean Cordillera ("várzeas" or "barriales" of "agua branca" rivers) are base-rich and have a clay-mineralogy of high physicochemical activity. They support a luxuriant forest cover, often with many palm species, or rich natural grasslands where the hydrological regime impedes tree growth.

The rivers originating in the crystalline shield areas or in the sedimentary basin itself carry little or no sediments and may contain high percentages of humic acids ("varzeas" and "igapos" of "agua azul" or "agua preta" rivers). The resulting soils are predominantly acid, with clay minerals of lower activity, and the forest cover is less luxuriant.
2.4.2. In the western part of the Amazon region extensive BOTTOMLAND COMPLEXES (Fb) occur. The largest area is the Pastaza-Marañon basin of Peru-Ecuador, which is in fact a huge Late Pleistocene-Holocene aggrading alluvial fan of approximately $60.000 \mathrm{~km}^{2}$ (Räsänen, 1991). The soils of these bottomlands are predominantly poorly drained and in part peaty (Histosols; humic and eutric Gleysols) and the vegetation is forest with a high frequency of palms.

2.4.3. Along the Atlantic coast and on Marajó island in the mouth of the river system COASTAL LOWLANDS (Fc) occur. Their soils are, or have been, subject to the influence of brackish or salt water (Solonchak, thionic Fluvisols, Gleysols). The natural vegetation is mangrove forest or grassland, the latter on the central and northern parts of Marajó island.

\section{SPECIES DIVERSITY, ENDEMISM AND REFUGIA}

\subsection{Definitions}

The foregoing descriptions and tentative dating of major landformssoils-vegetation structures, as spatial combinations of habitats, allow for a discussion of the geographical aspects of the Amazon biological diversity in general, and the species diversity in particular, with some notes on species endemism and speciation.

BIOLOGICAL DIVERSITY, defined as the variety and variability among living organisms and the ecological complexes in which they occur, has three levels: ecosystem diversity, 
species diversity and genetic diversity (McNeeley et al., 1990). The ECOSYSTEM DIVERSITY, reflected in the variety of habitats, biotic communities and ecological processes, has been implicitly described in the preceding chapter. The term SPECIES DIVERSITY refers to the variety of living organisms, while the GENETIC DIVERSITY refers to the sum total of the genetic information contained in the genes of individual plants, animals, and microorganisms.

Species diversity (or heterogeneity) combines species richness with species evenness (Magurran, 1988). Species richness is the number of different species in an area expressed per size unit of land (for instance per $\mathrm{km}^{2}$ ); species evenness is the degree of equal abundance of the different species within this unit of land. Thus, the more species and the more equally abundant they are, the greater the species diversity.

The measurement of species diversity is habitat-related (habitat being defined as the type of site where a plant or animal naturally and normally lives and grows). Whittaker (1977) distinguishes ALPHA-diversity (the within-homogeneous-habitat diversity); BETA-diversity (the between-habitat diversity, or the degree of difference between two contrasting habitats in their species composition as measured along an ecological gradient); GAMMA-diversity (the diversity of a large geographic unit such as an island or a major landscape, i.e. the over-all diversity of a group of alpha diversities; in other words, the richness in species of a range of habitats in the geographic unit, as the consequence of the alpha diversity of the habitats together with the extent of the beta diversity between them); and EPSILON diversity (the total diversity of a group of areas, as applying to large bio-geographic regions or "biomes").

When taking the foregoing description of the major landform-soil units, i.e. landscapes or "land systems" within the Amazon region as framework, it should be evident that species diversity in the following discussion is essentially of the gamma type.

Related to beta diversity is the concept of ENDEMISM: a species occurs only in a certain area and nowhere else, thus it has an ecological niche specificity; it is native, restricted or peculiar to a locality or region (McNeely et al., 1990).

Genetic diversity includes both INTRA-SPECIFIC VARIATION (i.e. a large variation in observable character among individuals belonging to the same species, or germ-plasm variation) and SPECIATION (i.e. the formation of a new species). According to Krebs (1984) such speciation can be "allopatric" (having disjunct or mutually exclusive areas of geographic distribution), "parapatric" (occupation of a new habitat which is adjoining the original area of geographic distribution), or "sympatric" (having the same or overlapping areas of geographic distribution). Allopatric genetic diversity in particular is supposed to be stimulated by a long-time presence of 
a biome in the same geographic area, with only minor changes in the environment (stability of climatic and landform-soil conditions). It is therefore linked to the concept of forest REFUGIA: small and disjunct areas where forest coverage would have been present throughout the Late Tertiary and the Pleistocene (Whitmore \& Prance, 1987).

The following short discussions on species diversity, endemism and speciation refer only to the plants, and trees in particular, but it may be taken that faunal and micro-organism communities are closely related.

\subsection{Species diversity}

Species diversity (of the gamma type as defined above) is bound to be highest in areas with a short-distance strong variation in habitat, in other words where landscapes or land systems are composed of land facets of strongly different topography, soil, hydrological and micro-climatic conditions. These situations can be found in areas where geo-morphogenetic processes were active in several episodes of the Pleistocene, as the result of periodic changes in pluviosity, linked with glaciations in the higher latitudes and altitudes and concurrent lowering in base level of the hydrographic catchments. Especially where such geomorphologic activity resulted in exposure of fresh rocks of short-distance contrasting lithology and mineralogy, the new pedogenesis resulted in soils of different depth, drainage condition, nutrient content, clay mineral assemblage and trace elements occurrence. This would allow many floristic species to find their required habitat for growth, reproduction and seed dispersal.

From the descriptions of major landform-soil units in section 2, and the schematic cross section of figure $2 \mathrm{a}$ it may be obvious that such conditions can be found most pronouncedly in the steepland-and-valley complexes of the Selva Alta area (unit S of the maplet); on the crystalline shield uplands with their convex slopes (Uc); on the inselberg complexes (I), and on the eutric variant (Ue) of the western sedimentary plains. To a lesser degree it applies to the dystrophic eastern and western sedimentary uplands (Uf and Ua, respectively) because of the relatively monotonous nature of the parent materials. However, high biodiversity is to expected where these sedimentary uplands are crossed by sand-filled former riverbeds, such as in the Manicoré-Novo Aripuanã area east of the lower Madeira river. The same may hold for those parts of the loamy plains that have been remodelled into low terraces, with intricate patterns of black and white-water lakes as a result .An example is the left side of the lower Purus river, which has an abundancy of primate species (Roosmalen, pers.comm). A similar case is formed by the floodplain complexes (F) of the "agua branca" rivers originating in the Andean Cordillera: the fluvial dynamics during the Late Pleistocene and the Holocene has caused rapid temporal 
and spatial vegetation successions due to changing sedimentological and hydrological habitats, as demonstrated by Salo \& Räsänen (1988).

\subsection{Species endemism}

Endemism, or the restriction in occurrence of certain species to specific areas within the Amazon tropical forest biome, is likely to be linked to extreme climatic, hydrological or soil conditions where such species have a relative advantage in the competition with other species.

Some tree species find their niche in conditions of year-long excessive rainfall such as the upper Colombian part of the Amazon region; others apparently thrive in areas with a strong dry season, such as large parts of the southern and southeastern fringe. This applies for instance to the prized timber species Cedro (Cedrela odorata) and Mahogany (Swietenia macrophilla), and the nut-producing Castanha-do-Pará (Bertholletia excelsa). Within this zoning a species may still require a specific edaphic habitat, as shown by a special study on Mahogany occurrence carried out by a FAO/SPVEA forest inventory team in 1961 in the Lower Araguaia area. The Mahogany species was found to be concentrated on well-developed hydromorphic soils with a high physico-chemical activity ("hydromorphic grey podzolic soils", or gleyic Luvisols; Sombroek, 1966, p. 203-208 and maplets).

Extreme hydrological conditions are found in the various floodplains and bottomlands; their influence on species endemism is discussed in detail by Junk (1984) and others.

Amongst extreme soil conditions the white-sand soils of the sandy plains $(\mathrm{Pa})$ and part of the table lands (T) and inselberg complexes (I) stand out. The specific floristic species composition of the "campina" and "caatinga amazônica" vegetative cover is rather well documented. It has a low degree of species diversity but a high number of endemic species (Ducke \& Black, 1953; Murça Pires, 1978; Anderson, 1981; Jordan, 1989).

The floristic composition of the various shallow soils of the table lands and inselberg complexes is less well known, with the exception of those of the Venezuelan "tepuis" (Huber, 1982 et seq.).

The author is not aware of any endemism-oriented study of the species composition of the loamy plains (Pp) with their imperfectly drained Plinthosols or plinthic Acrisols. In the parts with savanna vegetation, such as the "campos" of Humaitá-Lábrea, sclerophyllous and fire-resistant tree and shrub species are found that are also common in the "cerrado" areas of central Brazil (Ducke and Black, 1954); they would qualify as endemic only within the context of the Amazon forest region.

The forests in the areas with Nitisols on the shield uplands (minor parts of the Uc unit, only partially delineated on fig. 1 as Uce) reportedly have an aberrant tree species composition, viz. more light-timber species 
(Ducke \& Black, 1954). The nutrientrich soils of the western sedimentary uplands with a surmised or established influence of volcanic ash (sub-unit Uae) may also have several endemic species. The rubber tree (Hevea brasiliensis) is especially frequent in the unit, unless the vegetative cover has become a bamboo forest.

Even in the areas with a seemingly monotonous cover of welldrained acid yellowish soils (xanthic Ferralsols) of the eastern sedimentary uplands (Uf) and the Amazon planalto (A) there are phyto-geographic differences. This applies for instance (Sombroek, 1966, p. 198-203) to the occurrence of the valuable tree species Angelim-pedra (Hymenolobium excelsum). It is found predominantly on non-compacted soils of the Belterra clay, either in its original position on the Amazon planalto or in remodelled form in the associated relict valley parts of lower level. Another soughtafter timber species, the Pau-amarelo (Euxilophora paraensis) is found only on soils with a substratum of plinthitic or concretionary material of the "Ipixuna" type, which immediately overlies bauxitic material as occurring in the Paragominas area south of Belém; in both cases a specific micronutrient content of the substratum is surmised to be the determining factor.

Detailed comparison of the data on individual soil and forest inventory samples of Radambrasil (1972-1981) would doubtless result in more of such relationships.

\subsection{Speciation and refugia}

As discussed in 3.1, areas with large intra-specific variation and the evolution of new species, as forms of genetic diversity, are supposed to occur where past climatic, geomorphologic and soil conditions were not much different from those of today. It is rather commonly held that large parts of the present-day Amazon region were devoid of a forest coverage during several parts of the Late Tertiary and the Pleistocene, due to the occurrence of times of aridity, or interpluvials, which would have coincided with glacials in the higher latitudes and altitudes. Only in isolated parts forests would have been able to survive as refuge areas or refugia, and in such areas genetic diversity of the allopatric type would be highest. Maplets about those Amazon areas where humid tropical forest probably persisted during the last glacial (Winconsin/Würm) are given by Brown \& Ab'Saber (1979) and Brown (1987).

The validity of the location of these refugia is much debated these days, in part because of the geographically unbalanced amount of ground truth about the floristic and faunal species (Whitmore \& Prance, 1987; Colinvaux, 1987). However, from a geomorphologic point-of-view, sites of high genetic diversity are likely to be found on the sandstone table lands (T), on the Amazon planalto stretches (A) and in the areas of relict valleys (V). These are all stable landscapes, were soils development continued uninter- 
ruptedly since the Early Pleistocene, resulting in strongly weathered and often very deep soils. The rather extreme soil conditions of these geomorphic units, especially the table lands and the Amazon planalto (sandiness, subsoil compactness, very low clay mineral activity, strong acidity, lack of weatherable minerals) would be a detrimental factor for the survival of a number of forest species in-loco, especially during times of droughty conditions in the region as a whole. It is hereby postulated that, at the advance of such times, the forest species gradually moved to the edges and scarps of the table lands and the Planalto stretches. The occurrence of less extreme soil conditions, the presence of seepage water, and the likelihood of more orographic rainfall at the windward sides of these scarps would allow for survival of the species. It would creep back to the flat tops at the return of pluvial conditions in the region-at-large. A case in point for such a parapatric speciation may be the relatively high and steep scarps $(100-200 \mathrm{~m})$ of the planalto stretches of the upper Gurupi catchment, on the boundary of Pará and Maranhão states of Brazil, which is one of the suggested refugia.

In the case of the relict valleys (V) at the southern fringe of the phyto-geographic Amazon region, the forest vegetation would have temporarily withdrawn to narrow fringes of gallery forest in the lower parts of the stable concave-slope landscape, where a steady supply of groundwater would recom- pense for a seasonal shortage of rainfall.

Detailed multidisciplinary studies are needed to establish geographic relationship between speciation, past climatic conditions, stability of landforms and uninterrupted soil development during successive geologic periods, before more definite conclusions can be drawn on the validity of the refugia concept and their precise location.

\section{ACKNOWLEDGMENTS}

The author gratefully acknowledges the comments and suggestions of Prof. Salle Kroonenberg of Wageningen University on geomorphological aspects, and those of Dr. Hanna Tuomisto of Turku University in Finland on species diversity aspects.

\section{Literature cited}

Ab'Saber, A.N. 1967, Problemas geomorfológicos da Amazonia Brasileira. Atas do Simpósio sobre biota amazônica. Rio de Janeiro, Vol. I: 35-67.

Anderson, A. 1981. White-sand vegetation of Brazilian Amazonia. Biotropica 13(3):199-210.

Balée, W.; Campbell, D.G. 1989. Evidence for the successional status of liana forest (Xingu river basin, Amazonian Brazil). Biotropica (in press), See also: New York Botanical Garden's periodical "Garden" 11(6) of 1987.

Brown, K.; Ab'Saber, A. 1979. Ice-age forest refuges and evolution in the Neotropics. Instituto de Geografia, Universidade de São Paulo.

Brown, K. 1987. Soils and Vegetation. In: T.C. Whitmore; G.T. Prance. Biogeography and Quaternary History in Tropical America. - Clarendon Press, Oxford, p. 20-44.

Camargo, M.N. 1981. Mapa de Solos do Brasil, escala 1:5.000.000. EMBRAPASNLCS, Rio de Janeiro. 
Campbell, E.; Frailey, C.D.; Arellano, J. 1985. The Geology of the Rio Beni: further evidence for Holocene flooding in Amazonia. Contributions in Science 364, Natural History Museum of Los Angeles.

Cardoso da Silva, T.; Pereira de Araujo, A., Luiz de Carvalho, A. 1990. Diagnóstico Geoambiental e Sócio-economico da Área de influência da BR-364, trecho Porto Velho/Rio Branco. PMACI-I report, IBGE, Rio de Janeiro.

Carneiro Filho, A. 1991. Contribution to the study of the forest-savanna mosaic in the area of Roraima, northern Amazon basin, Brazil. Unpublished M.Sc. thesis, ITCEnschede, Holland.

Carneiro Filho, A.; Zinck, J.A. 1994. Mapping paleo-aeolian sand cover formations in the northern Amazon basin from TM images. ITC Journal, 1994:270-282.

Cochrane, T.T.; Sánchez, L.G.; de Azevedo, L.G.; Porras J.A.; Carver, C.L., 1985. Land in Tropical America. Vol. 1, 2, 3 (with land systems map of the central lowlands of tropical South America at scale 1:5.000.000). EMBRAPA-CPAC, Planaltina, D.F. Brasil, and CIAT, Cali, Colombia.

Colinvaux, P. 1987. Amazon Diversity in Light of the Paleo-ecological Record. Quaternary Science Reviews 6:93-114.

CPRM,1997. Projeto de Zoneamento Ecologico-Economico da Regiao Fronteiriça Brasil-Colombia, Eixo Tabatinga-Apaporis. Tome II. CPRM, Brasilia/Manaus

Ducke, A.; Black, G.A. 1954. Phytogeographical notes on the Brazilian Amazon. Anais Acad. Bras. de Ciencias 25(1):1-46.

Duivenvoorden, J.F; Lips, J.M. 1995. A landecological study of soils, vegetation and plant diversity in Colombian Amazonia. Tropenbos Series 12. Backhuys Publishers, Leiden.

FAO. 1974. FAO-Unesco Soil Map of the World 1:5.000.000. Volume I, Legend. Unesco, Paris.

FAO. 1988. FAO-Unesco Soil Map of the World. Revised Legend. FAO World Soil
Resources Report 60. Rome.

Frailey, C.D.; Lavina, E.L.; Rancy, A.; de Souza Filho, J.P. 1988. A proposed Pleistocene/Holocene Lake in the Amazon Basin and its Significance to Amazonian Geology and Biogeography. Acta Amazonica 18(3/4): 119-143.

Huber, O. 1982. Esbozo de las Formaciones Vegetales del Territorio Federal Amazonas, Venezuela. MARNR Serie Informe Tecnico DGSIIA/IT/103, Caracas.

Irion, G. 1976. Quaternary sediments of the Upper Amazon Lowlands of Brazil. Biogeographica 7:163-167.

Jordan, C.F. (ed.) 1989. An Amazonian Rain Forest; the structure and function of a nutrient-stressed ecosystem and the impact of slash-and-burn agriculture. Man and the Biosphere Series 2, Unesco, Paris, pp. 176.

Junk, W.J. 1984, Ecology of the Várzea, floodplain of Amazonian white-water rivers. In: H. Sioli, 1984. The Amazon, limnology and landscape ecology of a mighty tropical river and its basin. Dr. W. Junk Publishers, Dordrecht/Boston/Lancaster:215-243.

Kauffman, J.H.; Paredes, G.; Marquina, R. 1998. Suelos de la zona de Iquitos. In: Kalliola, R.; Paitan, F. (eds.) Geoecologia $y$ desarrollo de ela zona de Iquitos, Peru. (english version: Kauffman, J.H.; Paredes, G.; Marquina, R. 1998. Soils of the Iquitos region, Peru, soil variation and land management. Report 98/02. ISRIC, Wageningen).

King, L.C. 1957. A geomorfologia do Brasil Oriental. Separata Rev. Bras, de Geogr., Rio de Janeiro (2): 147-265.

Klammer, G. 1984. The relief of the extraAndean Amazon basin. In: H. Sioli, 1984. The Amazon; limnology and landscape ecology of a mighty tropical river and its basin. Dr. W. Junk Publishers, Dordrecht/ Boston/Lancaster: 47-83.

Khobsi, J.; Kroonenberg, S.; Faivre, P.; Weeda, A. 1980. Aspectos geomorfologicos de la Amazonia y Orinoquia Colombiana. Revista CIAF 5:97-126, Bogota. 
Krebs, Ch.J. 1984. Ecology; the experimental analysis of distribution and abundance. Harper and Row, New York.

Kubitzki, K. 1989. Amazonas-Tiefland und Guayana-Hochland; historische und ökologische Aspekte ihrer Florenentwicklung. Amazoniana XI(1):112.

Magurran, A.E. 1988. Ecological diversity and its measurement. Croom Helm Ltd,, London.

Marbut, C.F. 1932. Morphology of laterites. Trans. Intern. Congr. Soil Science II, Moscow 1932. Vol. V:72-80.

McConnell, R.B.; Masson-Smith, D.; and Berrange, J.P. 1969. Geological and geophysical evidence of a rift valley in the Guiana shield. Geologie en Mijnbouw 48(2):189-199.

McNeely, J.A.; Miller, K.R; Reid, W.V. 1990. Conserving the world's biological diversity. IUCN, Gland, Switzerland; WRI, Conservation International, WWF-US and Worldbank, Washington, D.C.

Möller, M.R.F.; Kitagawa, Y. 1982. Mineralogia de argilas em Cambissolos do Sudoeste da Amazonia brasileira. Boletim de Pesquisa 34, EMBRAPA-CPATU, Belém, Brazil.

Murça-Pires, J, 1978. The forest ecosystems of the Brazilian Amazon: description, functioning and research needs. $I n$ : Tropical Forest Ecosystems. Natural Resources Research 14, Unesco, Paris p607-627.

Proradam, 1979. La Amazonia Colombiana y sus Recursos. Proyecto Radargrametico del Amazonas, Bogotá, Vol. I-V.

Radambrasil 1972-1981. Levantamento de Recursos Naturais, Vol. 1-26. Ministério das Minas e Energia/IBGE, Rio de Janeiro.

Räsänen, M.E. 1991, History of the fluvial and alluvial landscapes of the western Amazon andean forelands. Annales Universitaties Turkuensis, Ser. A. 75. The Academic Bookstore, Helsinki.
Räsänen, M.E.; Salo, J.S.; Kalliola, R.J. 1987. Fluvial Perturbance in the Western Amazon River Basin: regulation by long-term sub-Andean tectonics. Science 238:13981401.

Ruokalainen, K,; Tuomista, H. 1998. Vegetación natural de la zona de Iquitos. In: Kalliola, R. and Paitan, F., eds. Geoecologia y desarrollo de la zona de Iquitos, Peru.

SAI/IBGE.1998. Diagnostico Ambiental da Amazonia Legal: Mapa de Geologia 1:2.500.000. IBGE, Rio de Janeiro

Salo, J.; Räsänen, M. 1989. Hierarchy of Landscape Patterns in Western Amazon, In: L.B. Holm-Nielsen, I.C. Nielsen and H. Balslev. Tropical Forests; Botanical dynamics, speciation and diversity. Academic Press, London.

Sombroek, W.G. 1966. Amazon Soils; a reconnaissance of the soils of the Brazilian Amazon region. Centre for Agricultural Publications and Documentation PUDOC, Wageningen, pp. $302+$ maps.

Sombroek, W.G. 1984. Soils of the Amazon Region. In: H. Sioli 1984. The Amazon, limnology and landscape ecology of a mighty tropical river and its basin. Dr. W. Junk Publishers, Dordrecht/Boston/ Lancaster:521-536.

Sombroek, W.G.; Duran, A.; Averbeck, H. 1970. Soil studies in the Laguna Merin Basin (Uruguay-southeast Brazil). Technical Report LM-131, CLM/FAO, Treinta y Tres, Uruguay, pp. $300+$ maps.

Sutmöller, P.; Vahia de Abreu, A.; van der Grift, J.; Sombroek, W.G. 1966. Mineral imbalances in cattle in the Amazon valley. Communication 53, Royal Tropical Institute, Amsterdam.

Whittaker, R.H. 1977. Evolution of species diversity in land communities. Evolutionary Biology 10, Plenum, New York:1-67.

Zeuner, F.E. 1959. The Pleistocene period. Its climate, chronology and faunal successions. Hutchinson Scientific and Technical, London. 